\title{
Predicting the Volume Need for Architectural Work Using Artificial Neural Networks in Hospital Buildings
}

\author{
Aulia Yudha Prathama ${ }^{*}$ \\ 1 Audit Board of Indonesia, Central Jakarta, INDONESIA \\ *Corresponding authors: aulia.yudha.prathama@mail.ugm.ac.id
}

SUBMITTED 18 October 2018 REVISED 12 December 2018 ACCEPTED 14 January 2019

\begin{abstract}
Decision-making in construction design has an important role. The need for estimation tools of planning and project management aspects needs to develop. This paper discussed the benefits of artificial neural network methodology to overcome the problem of estimated the needs of the volume of wall paired, ceiling worked pairing, and ceramic floor pairing for architectural work at the designed stage of the building. The average architecture cost of state building is $29 \%-51 \%$ of total construction value. Data from 15 projects was used for being trained and tested by Artificial Neural Network (ANN) methods with 5 design input variables. The ANN helped to estimate the value of volume requirement on the architectural working of Pratama Hospital building project in remote areas of Indonesia. Those input variables include building area, average column span distance, the height of the building, the shape of the building, and a number of inpatient rooms. From ANN simulation, the best empirical equation of P2V5 modeling was used to predict the need of hospital architecture work volume at conceptual stage with best ANN structure 5-9-3 (5 input variables, 1 hidden layer with 9 neurons and 3 output) with result of estimation accuracy a maximum of $96.40 \%$ was reached.
\end{abstract}

KEYWORDS Artificial Neural Network; building design; conceptual stage; the estimated volume of work; hospital building

(c) The Author(s) 2018. This article is distributed under a Creative Commons Attribution-Share Alike 4.0 International license.

\section{INTRODUCTION}

The design of architectural work has essential affect to the total cost of construction. The value of architectural work itself has a considerable allocation of the total contract, ranges from $29-51 \%$ and it is one of the important work packages in a building construction work. The architectural work package items used for the work of wall pairs are allocated at \pm $33 \%$, for the job of plafond pairs of $\pm 8 \%$, and for the work of ceramic floor pairs of $\pm 13 \%$. The use of those components of the work is most widely used for building buildings in Indonesia, one of them was used at the building Pratama Hospital. For the type of building Pratama Hospital component of those work has a value of work of $\pm 21 \%$ of the total value of construction contracts. The overall cost of a building can be decreased considerably if the volume of architectural work is designed efficiently. Therefore, both the architect and the engineer must be careful in making the design decisions for the planned related to the volume requirements of the architectural components to be used.

The purpose of this study is for designing estimation methods of the volume needs of wall pairs, ceiling and floor tiles for hospital building and intuitive assessment by utilized the experience and data of Pratama Hospital development from previous projects. The development of computer technology and software has provided the benefits of a new approach to cost estimation. With the advented of Artificial Intelligence (AI) tools (i.e., artificial neural networks) in terms of predicting the possibility of multi-and nonlinear relationships, the cost of structural work was investigated (Dogan, 2004). The authors expects to develop and test models and variables that influence the estimation of volumes of wall, ceiling and floor tiles for aesthetic work in conceptual building through the application of the Artificial Neural Network method. The Artificial Neural Network (ANN) model can contribute in decision making based on initial conditions on the design process. Using this method, it is expected to be able to predict and produce an accurate estimation formula, with information that can be known at the conceptual stage. This approach encourages a feedback process that can help planners and contractors to achieve optimal solutions.

The sample data used for cost estimation in this paper was derived from preliminary DED (Detail of Engineering) data on the construction of Pratama Hospital at the Ministry of Health in 2015 and 2017. As a developing country, Indonesia experiences rapid and 
parallel population growth which affects health service in the whole country. The development of Pratama Hospital has the purpose to facilitate and assist health services especially in remote areas of Indonesia in order to increase public services and public health. The lack of data, time constraints, and lack of resources that understand the calculation of the volume requirement for architectural work is a major problem at the level of policy makers within the Ministry of Health because only a few have competence on civil engineering. Thus, it is necessary to also review the factors that have a close correlation to the volume requirements of the working component on the architecture of the building of the Pratama Hospital. So that, a calculation method can be calculated for estimating the volume of needs on the work of wall pairs, ceilings, and ceramic floor using ANN method that can be used for control and forecast when the management of building material needs of RS Pratama building construction.

\section{METHOD}

\subsection{Design of ANN Architecture Model}

The problems presented in this paper were based on design and prediction optimization in configuring neural network architecture feedback and back propagation learning techniques.

MATLAB software and excel spreadsheets were used for modeling. The model has been developed in three stages: modeling phase, the training phase, and testing phase. Modeling stage involved data analysis, identification of variables estimating the volume requirements of work components and selection of network architecture. In the modeling stage, the selected variables are the variables that can be known at the conceptual stage such as examples: building area, height of building, shape of building, etc. The training phase requires data preparation and application of learned algorithms for training. The testing phase evaluated the predictive accuracy of the ANN model to the actual volume requirement compared to the ANN volume estimate and the percentage of volume requirement errors then it can be calculated.

\subsection{Modeling Stage}

The modeling stage included designing ANN architecture. This stage is a complex and dynamic process that required the determination of modeling structures and internal rules. (i.e., the number of hidden layers and neurons and the type of activation function). This model is designed according to the type of data and response required by the ANN application. In this modeling will be divided into four kinds of modeling with two types of variation variables that is with three and five inputted variables.

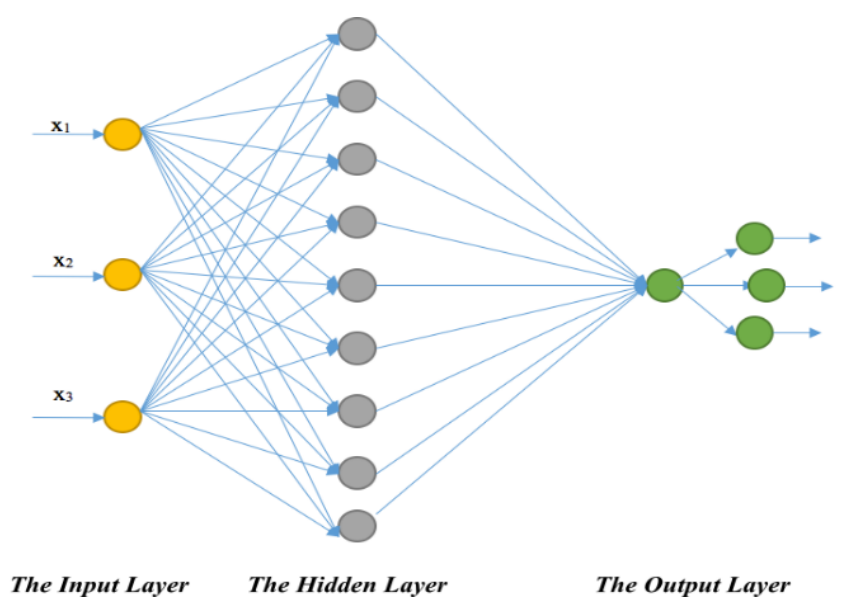

Figure 1. Neural Network Architecture Model with 3 Input Variables

Modeling P1V3 (Procedure 1 with 3 input variables) and P2V3 P1V3 (Procedure 2 with 3 input variables) ANN architecture model can be seen in Figure 1 and for modeling P1V5 (Procedure 1 with 5 input variables) and P2V5 (Procedure 2 with 5 input variables) can be seen in Figure 2. This ANN model has been designed to include the input layer of three processing elements (neurons) that correspond to the three input parameters and the output layer of a processing element (neuron) as the target. One hidden layer of the nine process elements selected after several experiments during the testing phase. The hidden layer functions are extracting and remembering useful features. Sub features of the input pattern then used to predict network output or output layer values (Kusumadewi, 2004). Therefore, the number of effective processing elements are usually determined by testing for a hidden layer, since there is no rule to determine it. The ANN model is empirically formed, not based on theoretical origin. The key parameters (i.e., conceptual building design variables) for the input layer are selected from the analysis of the experimental data to evaluated the results of the data output (the requirement of the concrete volume) shown in Table 1. 


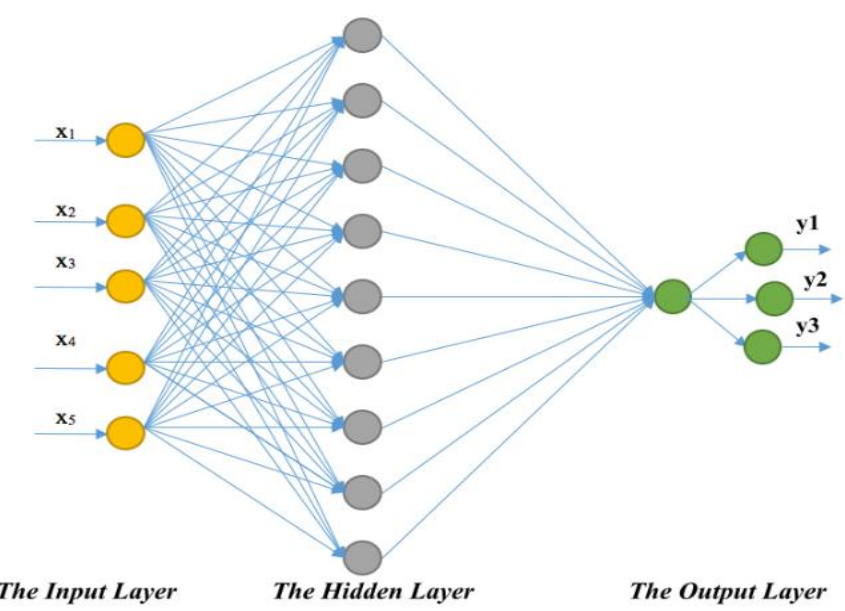

Figure 2. Neural Network Architecture Model with 5 Input Variables

Table 1. Variable Model Design ANN

\begin{tabular}{|c|c|c|}
\hline Variable & Definition & Data range \\
\hline$X_{1}$ & Building area & $1194.69-4792.40 \mathrm{~m}^{2}$ \\
\hline$X_{2}$ & $\begin{array}{l}\text { Average column } \\
\text { span }\end{array}$ & $3.43-5.46 \mathrm{~m}$ \\
\hline$X_{3}$ & Building height & $7.49-26.21 \mathrm{~m}$ \\
\hline$X_{4}$ & $\begin{array}{l}\text { The shape of the } \\
\text { building }\end{array}$ & $1-4$ \\
\hline$X_{5}$ & $\begin{array}{l}\text { Number of } \\
\text { inpatient rooms }\end{array}$ & $2-16$ \\
\hline$Y_{1}$ & $\begin{array}{l}\text { The working } \\
\text { volume of wall pairs }\end{array}$ & $1691.44-5818.06 \mathrm{~m}^{2}$ \\
\hline$Y_{2}$ & $\begin{array}{l}\text { The volume of work } \\
\text { ceiling }\end{array}$ & $958.19-3602.84 \mathrm{~m}^{2}$ \\
\hline$Y_{3}$ & $\begin{array}{l}\text { The volume of } \\
\text { ceramic floor work }\end{array}$ & $897.69-4293.43 \mathrm{~m}^{2}$ \\
\hline
\end{tabular}

Table 2. Description of variables $X_{4}$ and $X_{5}$

\begin{tabular}{|c|c|c|}
\hline \multicolumn{3}{|l|}{ Information } \\
\hline $\begin{array}{l}\text { The shape } \\
\text { of the } \\
\text { building }\end{array}$ & $\begin{array}{l}1= \\
2= \\
3= \\
4=\end{array}$ & $\begin{array}{l}\text { Building shape with } 1 \text { void } \\
\text { Building shape with } 2 \text { voids } \\
\text { Separate buildings form } \\
\text { Form of high-rise buildings }>1\end{array}$ \\
\hline $\begin{array}{l}\text { Number of } \\
\text { inpatient } \\
\text { rooms }\end{array}$ & $2-16$ & $\begin{array}{l}\text { Accordance with the number of } \\
\text { inpatient rooms that want to be } \\
\text { provided in building Pratama } \\
\text { Hospital }\end{array}$ \\
\hline
\end{tabular}

The estimation model of architectural volume requirements is based on the following design variables and corresponding output targets on the picture (Figure 1). Components that we can know in conceptual variables consist of 3 basic variables namely building area, average column span, and height of the building. Modeling with 3 variables is differentiated between P1V3. That is modeling with 3 variables used 15 data as training data without used validation data. For P2V3 modeling, that is modeling with 3 variables used 10 data as training data, and 5 data as validation data of the result of training. Based on these two modeling will be obtained the value of constants generated by MATLAB program. After obtained the constant value of this modeling, with the help of Microsoft Excel analysis will be produced that employs the empirical modeling formulas for P1V3 and $\mathrm{P} 2 \mathrm{~V} 3$. The calculation results from the empirical formula, then it can be used to predict the value of the output to be searched, in this case, the output to be sought is the need of volume of work of wall pairs, ceiling, and ceramic floor for the project of Pratama Hospital building. Then the result of the required volume value based on ANN will be compared with the actual volume requirement of architectural work to know the value of percentage error/ MMRE. The comparison value of the error/ MMRE result between P1V3 and P2V3 modeling will be compared to obtain the smallest ANN modeling formula value/ MMRE error. P1V5 and P2V5 modeling which used 5 input variables will be used to look for the smallest error/ MMRE value, for later used as a result of the empirical formula for estimated the need for the volume of architectural work in the RS Pratama project.

The ANN model with these five input variables has been designed to include the input layer of the five processing elements (neurons) corresponding to the five input parameters and one output layer of a processing element (neuron) as the target. One hidden layer of the nine process elements is selected after several experiments during the testing phase. Modeling with 5 variables is differentiated between P1V5. That is modeling with 5 variables using 15 data as training data without used validation data. For P2V5 model, that is modeling with 5 variables used 10 data as training data, and 5 data as validation data result from training. Numerical assessment for the $X_{4}$ variables of the building form and $X_{4}$ for the number of rooms of inpatient rooms can be seen in Table 2 as the conversion into the numerical data approach.

\subsection{Training Stage}

There are many other alternative procedures to choose from. Back propagation algorithm is a suitable method applied to this method. Training is the most widely used training technique for problems similar to current research (Hegazy, 1998). This back propagation algorithm method has been proven theoretically and performs well in modeling nonlinear functions, as well as easy to encode (Kesturi, 2012). The addition of algorithmic function to the activation rule that regulated the weight adjustment between neurons, the 
hyperbolic tangent function used in the modeling stage, the other basic rules of the network is related to the learning/training function. The steps in the training phase are as follows:

1) Specified the input and output parameters to be used.

The general equation of ANN (Equation 1):

$$
T_{k}><Y_{k}=\left(b_{2 k}+\left(\sum W_{j k} \cdot f\left(b_{i j}+\sum V_{i j} \cdot X_{i}\right)\right)\right)
$$

where $T_{k}$ is output targets installed value of the volume of work needs wall pairs, ceilings, and floor tiles, $Y_{k}$ is forecast output, $b_{2 k}$ is the weight of bias layer, $W_{j k}$ is weight layer, $b_{i j}$ is The weight of input bias, $V_{i j}$ is input weight and $X_{i}$ is Input parameters. $f$ is the transfer function/ activation used is (binary sigmoid function)

$f_{(\mathrm{x})}=\frac{1}{1+\mathrm{e}^{\wedge} \mathrm{x}}$

$f^{\prime}(x)=f(x)[1-f(x)]$

The sigmoid function normalized the input and output data generated from $0-1$.

2) Determining the activation function used for logsig activation function for 9 hidden layers and purlin for output and trainscg (trainscalegradient) as performance function which will make the weighting arrangement so that at the end of the training we will get the good weights.

3) Determined the network shape and parameters.

4) Entering data into the application program Artificial Neural Network Program MATLAB executed later in the editor window inserted back propagation programming algorithm, input data, and output target data to be processed.

5) From the ANN simulation result in MATLAB after the stopping function is achieved will be obtained data matrix which will be processed by using the help of excel software to produce the output of estimation data of architectural volume requirement.

\subsection{Test Phase}

The performance of the ANN model is measured using the estimated percentage error formula (MMRE) (Equation 4).
MMRE $=\frac{E(i)-T(i)}{T(i)} \times 100 \%$

with $E_{(i)}$ is forecasts of the value of the i output and $T_{(i)}$ is the target value of the actual $i$ output.

The effects generated from each network input on the network output can be analyzed. These effects provide feedback on which parameters of the inputs are most significant. In this ANN model, the building area, the spacing between the mean columns, the height of the building, the shape of the building, and the number of in-patient rooms are considered as design parameters at the most effective conceptual stage. In addition, the use of these five design variables had an average prediction accuracy effect of the best model of $98.60 \%$.

\section{RESULT AND DISCUSSION}

The result of estimation value of volume requirement of architectural work component in RS Pratama building from 4 kinds of modeling got value for each modeling as follows.

According to Table 3 and Table 4 regarding the smallest maximal MMRE error values, it can be seen that P2V5 modeling has the most approximate value to the actual volume requirement of wall, ceiling and floor tiles. P2V5 model shows an average accuracy of 98.60\% with the mean square of MSE (Mean Square Error) $6.1568 \times 10-6$ at 429 th iteration (Figure 3).

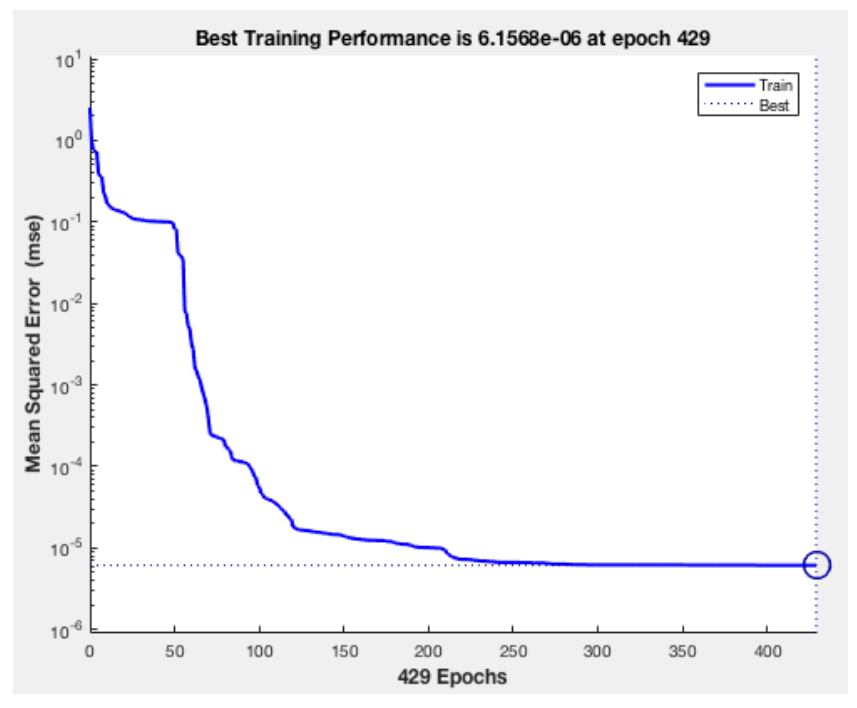

Figure 3. ANN P2V5 Model Training Chart 
Table 3. Comparison of ANN Modeling Results

\begin{tabular}{|c|c|c|c|c|c|c|c|c|c|c|c|c|c|c|c|}
\hline \multirow[b]{2}{*}{$\begin{array}{l}\text { Clus } \\
\text { ter }\end{array}$} & \multirow[b]{2}{*}{$\begin{array}{l}\text { Actual } \\
\text { wall pair } \\
\text { work } \\
\text { volume } \\
\text { value } \\
\left(\mathrm{m}^{2}\right)\end{array}$} & \multirow[b]{2}{*}{$\begin{array}{l}\text { Actual } \\
\text { plafond } \\
\text { volume } \\
\text { value } \\
\left(\mathrm{m}^{2}\right)\end{array}$} & \multirow[b]{2}{*}{$\begin{array}{l}\text { Actual } \\
\text { floor } \\
\text { volume } \\
\text { value } \\
\left(\mathrm{m}^{2}\right)\end{array}$} & \multicolumn{3}{|l|}{ P1V3 } & \multicolumn{3}{|l|}{ P2V3 } & \multicolumn{3}{|l|}{ P1V5 } & \multicolumn{3}{|l|}{ P2V5 } \\
\hline & & & & $\begin{array}{l}\text { Wall } \\
\text { pairing } \\
\text { volume } \\
\text { value by } \\
\text { ANN } \\
\left(\mathrm{m}^{2}\right)\end{array}$ & $\begin{array}{l}\text { Plafond } \\
\text { work } \\
\text { volume } \\
\text { by ANN } \\
\left(\mathrm{m}^{2}\right)\end{array}$ & $\begin{array}{l}\text { Floor } \\
\text { work } \\
\text { volume } \\
\text { by ANN } \\
\left(\mathrm{m}^{2}\right)\end{array}$ & $\begin{array}{l}\text { Wall pairing } \\
\text { volume } \\
\text { value by } \\
\text { ANN }\left(\mathrm{m}^{2}\right)\end{array}$ & $\begin{array}{l}\text { Plafond } \\
\text { work } \\
\text { volume by } \\
\text { ANN }\left(\mathrm{m}^{2}\right)\end{array}$ & $\begin{array}{l}\text { Floor } \\
\text { work } \\
\text { volume } \\
\text { by ANN } \\
\left(\mathrm{m}^{2}\right)\end{array}$ & $\begin{array}{l}\text { Wall pairing } \\
\text { volume } \\
\text { value by } \\
\text { ANN }\left(\mathrm{m}^{2}\right)\end{array}$ & $\begin{array}{l}\text { Plafond } \\
\text { work } \\
\text { volume by } \\
\text { ANN }\left(\mathrm{m}^{2}\right)\end{array}$ & $\begin{array}{l}\text { Floor } \\
\text { work } \\
\text { volume } \\
\text { by ANN } \\
\left(\mathrm{m}^{2}\right)\end{array}$ & $\begin{array}{l}\text { Wall } \\
\text { pairing } \\
\text { volume } \\
\text { value by } \\
\text { ANN } \\
\left(\mathrm{m}^{2}\right)\end{array}$ & $\begin{array}{l}\text { Plafond } \\
\text { work } \\
\text { volume } \\
\text { by ANN } \\
\left(\mathrm{m}^{2}\right)\end{array}$ & $\begin{array}{l}\text { Floor } \\
\text { work } \\
\text { volume } \\
\text { by ANN } \\
\left(\mathrm{m}^{2}\right)\end{array}$ \\
\hline 1 & 3772.58 & 2481.51 & 1869.29 & 3225.82 & 1903.69 & 1743.83 & 3863.79 & 2237.70 & 2099.86 & 3743.15 & 2455.14 & 1889.69 & 3849.25 & 2450.87 & 1843.86 \\
\hline 2 & 4003.93 & 2481.51 & 1869.29 & 3302.48 & 1946.80 & 1785.45 & 3722.27 & 2155.40 & 2023.04 & 3838.77 & 2466.45 & 1886.88 & 3937.06 & 2503.07 & 1891.21 \\
\hline 3 & 1691.44 & 958.19 & 897.69 & 1680.09 & 952.62 & 888.32 & 1619.46 & 922.29 & 854.11 & 1688.58 & 968.25 & 892.43 & 1667.22 & 957.70 & 877.67 \\
\hline 4 & 1691.44 & 958.19 & 897.69 & 1691.13 & 958.83 & 894.32 & 1679.51 & 957.49 & 886.89 & 1689.51 & 967.47 & 897.37 & 1687.53 & 966.23 & 894.84 \\
\hline 5 & 1691.44 & 958.19 & 897.69 & 1686.56 & 956.26 & 891.84 & 1653.35 & 942.16 & 872.61 & 1687.31 & 966.76 & 896.16 & 1678.75 & 962.60 & 887.35 \\
\hline 6 & 1691.44 & 978.38 & 897.69 & 1696.12 & 961.63 & 897.03 & 1699.12 & 968.99 & 897.59 & 1691.20 & 968.06 & 898.27 & 1694.74 & 969.51 & 900.44 \\
\hline 7 & 1691.44 & 978.38 & 897.69 & 1704.92 & 966.66 & 901.82 & 1733.38 & 989.07 & 916.33 & 1694.00 & 969.07 & 899.78 & 1706.38 & 974.65 & 909.67 \\
\hline 8 & 1691.44 & 978.38 & 897.69 & 1741.93 & 989.20 & 922.26 & 1799.91 & 1028.15 & 953.46 & 1695.95 & 969.79 & 900.86 & 1715.08 & 978.73 & 916.13 \\
\hline 9 & 5818.06 & 1903.24 & 2682.70 & 5806.51 & 1903.50 & 2687.33 & 4295.75 & 2428.20 & 2294.13 & 5817.68 & 1902.03 & 2682.95 & 5818.26 & 1903.51 & 2682.61 \\
\hline 10 & 4494.70 & 3602.84 & 4293.43 & 4748.68 & 2760.10 & 2570.83 & 4884.76 & 2838.51 & 2658.77 & 4494.45 & 3603.03 & 4293.58 & 4497.61 & 3601.81 & 4293.20 \\
\hline 11 & 3772.58 & 2481.51 & 1869.29 & 3269.29 & 1928.14 & 1767.43 & 3735.71 & 2163.14 & 2030.28 & 3887.58 & 2505.54 & 1841.64 & 3908.32 & 2486.35 & 1875.66 \\
\hline 12 & 3772.58 & 2481.51 & 1869.29 & 3249.99 & 1917.28 & 1756.95 & 3806.27 & 2204.22 & 2068.61 & 3812.92 & 2484.85 & 1872.23 & 3877.51 & 2467.78 & 1859.14 \\
\hline 13 & 1691.44 & 958.19 & 897.69 & 1698.31 & 962.87 & 898.22 & 1712.12 & 976.60 & 904.69 & 1692.32 & 968.45 & 898.87 & 1699.04 & 971.25 & 904.13 \\
\hline 14 & 1691.44 & 978.38 & 897.69 & 1694.48 & 960.71 & 896.14 & 1694.81 & 966.46 & 895.24 & 1690.83 & 967.92 & 898.07 & 1692.94 & 968.59 & 899.21 \\
\hline 15 & 4903.87 & 2181.07 & 2115.35 & 4449.30 & 2591.73 & 2408.25 & 5445.39 & 3167.09 & 2964.81 & 4893.40 & 2179.94 & 2119.29 & 4908.11 & 2178.37 & 2114.77 \\
\hline
\end{tabular}

Table 4. Percentage Error/ MMRE ANN Modeling

\begin{tabular}{|c|c|c|c|c|c|c|c|c|c|c|c|}
\hline \multirow[b]{2}{*}{ Modeling } & \multicolumn{3}{|l|}{ Error min } & \multirow[b]{2}{*}{ Modeling } & \multicolumn{3}{|l|}{ Error max } & \multirow[b]{2}{*}{ Modeling } & \multicolumn{3}{|c|}{ Error average } \\
\hline & $\begin{array}{l}\text { Wall pair } \\
\text { volume }\end{array}$ & $\begin{array}{l}\text { Work } \\
\text { ceiling } \\
\text { volume }\end{array}$ & $\begin{array}{l}\text { Floor } \\
\text { ceramic } \\
\text { volume }\end{array}$ & & $\begin{array}{l}\text { Wall pair } \\
\text { volume }\end{array}$ & $\begin{array}{l}\text { Work } \\
\text { ceiling } \\
\text { volume }\end{array}$ & $\begin{array}{l}\text { Floor } \\
\text { ceramic } \\
\text { volume }\end{array}$ & & $\begin{array}{l}\text { Wall pair } \\
\text { volume }\end{array}$ & $\begin{array}{l}\text { Work ceiling } \\
\text { volume }\end{array}$ & $\begin{array}{l}\text { Floor ceramic } \\
\text { volume }\end{array}$ \\
\hline P1V3 & 0.02 & 0.01 & 0.06 & P1V3 & 17.52 & 23.39 & 40.12 & P1V3 & 5.33 & 9.28 & 5.49 \\
\hline P2V3 (Training) & 0.45 & 0.07 & 0.01 & P2V3 (Training) & 26.17 & 27.58 & 38.07 & P2V3 (Training) & 6.09 & 8.44 & 9.03 \\
\hline P2V3 (Validation) & 0.20 & 1.22 & 0.27 & $\begin{array}{l}\text { P2V3 } \\
\text { (Validation) }\end{array}$ & 11.04 & 45.21 & 40.16 & $\begin{array}{l}\text { P2V3 } \\
\text { (Validation) }\end{array}$ & 2.87 & 14.47 & 12.10 \\
\hline P1V5 & 0.01 & 0.01 & 0.00 & P1V5 & 4.12 & 1.07 & 1.48 & P1V5 & 0.69 & 0.72 & 0.37 \\
\hline P2V5 (Training) & 0.00 & 0.05 & 0.31 & P2V5 (Training) & 2.03 & 1.23 & 2.23 & P2V5 (Training) & 0.87 & 0.73 & 1.09 \\
\hline P2V5 (Validation) & 0.09 & 0.12 & 0.03 & $\begin{array}{l}\text { P2V5 } \\
\text { (Validation) }\end{array}$ & 3.60 & 1.36 & 0.72 & $\begin{array}{l}\text { P2V5 } \\
\text { (Validation) }\end{array}$ & 1.40 & 0.65 & 0.36 \\
\hline
\end{tabular}


These figures are considered as value estimates of volume requirements of good architectural work components at the beginning of the conceptual stage of planning design to assess the value of architectural work. The results of this study also outperformed the Saner study resulted in a linear regression coefficient of only 0.47 ; while the current model is 0.99 close to 1 (Result of ANN model Figure 4). The maximum deviation of the estimated excess demand volume requirement of the architectural work component from the actual cost is about $3.60 \%$ while the mean deviation is around $1.40 \%$ (Table 4 ).

The accuracy of the cost estimate may be close to a professional expert system developed by Mohamed and Celik, in which the total estimated cost error is found between the $2 \%$ and $4 \%$ range of the actual cost. Of course, we must not forget that professional planners used more accurate information. While in this modeling using simple information that is easily obtained or determined at the conceptual stage before going to do the initial construction planning. In addition to obtained empirical formulas to find the value of the volume requirement of architectural components, we can graph the relationship between the needs of work volume of wall pairs, ceilings, and ceramic floor with the building area for each of 4 ANN modeling.

Estimated value of demand for work volume of wall pairs, ceilings, and tile floors can be found using plotting on graphic drawings. Based on the error/ MMRE value of four types of modeling, the value in the P2V5 modeling had the best value than the other modeling values. The graphs of each of the P2V5 modeling can be seen in Figures 5, 6, and 7. Using the graph we can look for the estimated value of the component requirement of the volume of architectural work by plotting the known value of the building area. Based on Table 5 we can see the description of the P2V5 modeling plot graph. Modeling P2V5 has the highest accuracy value compared with other ANN modeling, it is of course indicated that good ANN output result can be determined with the accuracy level of ANN modeling result. The accuracy value for P2V5 modeling had a percentage rate of $98.60 \%$. With the error comparison value for the volume validation of the needs of the architectural work components as in Table 6, 7, and 8.

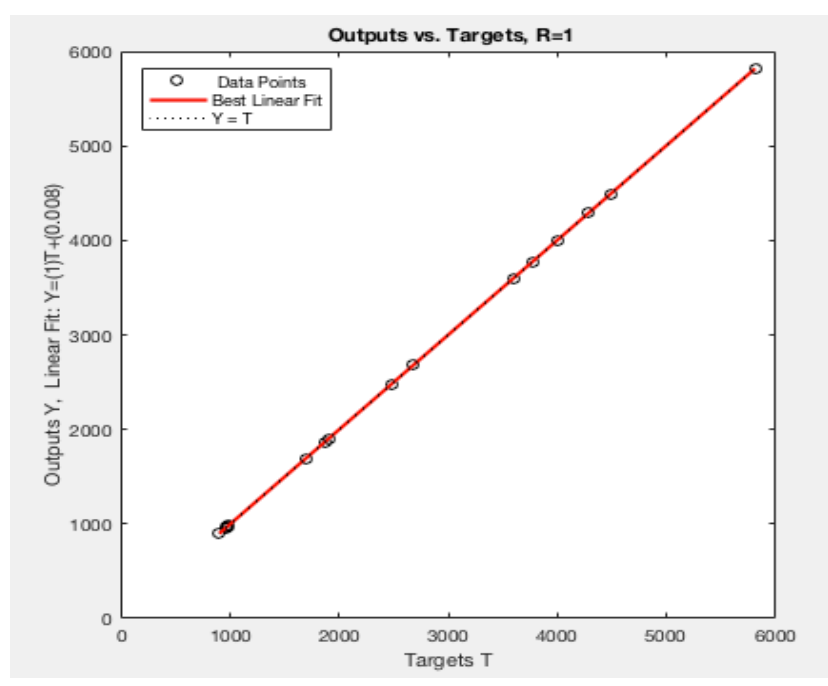

Figure 4. Regression Chart of P2V5 Modeling Results

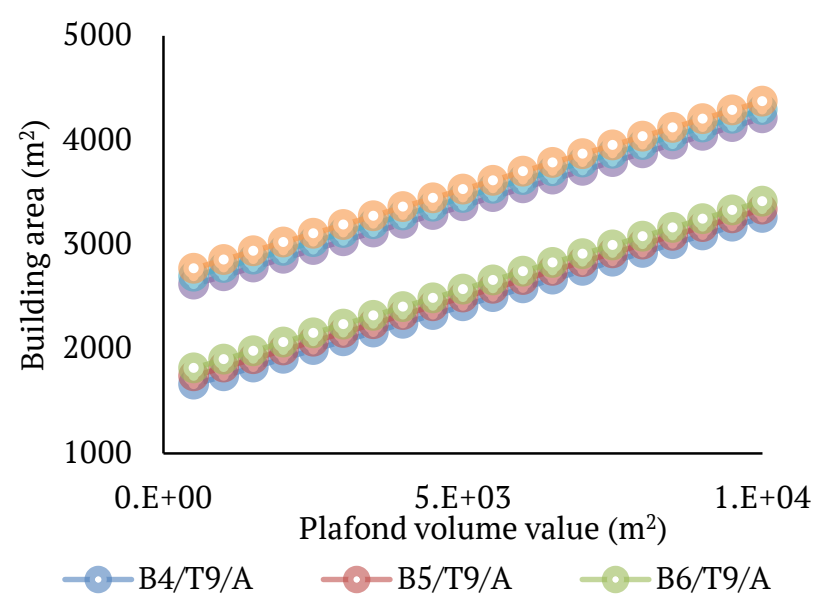

Figure 5. Graph of Plot Relationship Needs Volume of Working Pair of Plafond with Building Area Modeling P2V5

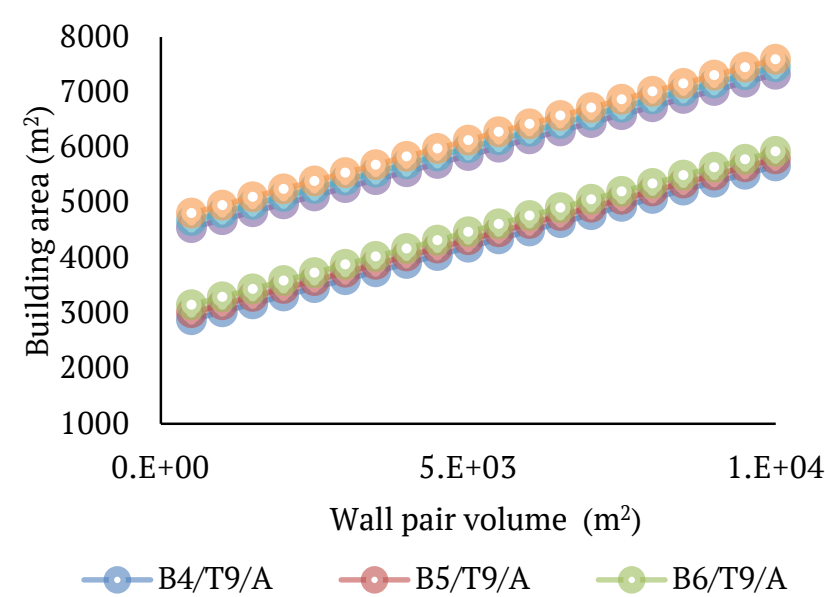

Figure 6. Graph of Plot Relationship Requirement Volume of Working Pairs of Walls with Building Area Modeling P2V5 


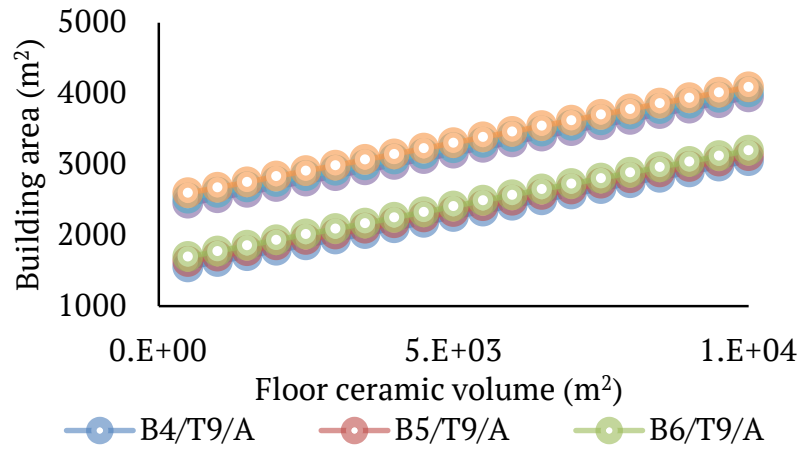

Figure 7. Graph of Plot Relationship Requirement Volume of Working of Ceramic Floor Pair with Building Area Modeling P2V5

Table 5. Description of the P2V5 Modeling Plot Graph

\begin{tabular}{|c|c|}
\hline $\begin{array}{l}\text { Structure } \\
\text { type }\end{array}$ & Information \\
\hline B4/T9/A & $\begin{array}{l}\text { Spanning distance between columns } 4 \mathrm{~m} \text {, } \\
\text { building height } 9 \mathrm{~m} \text {, number of inpatient } \\
\text { rooms } 10 \text { rooms, building form } 2 \text {. }\end{array}$ \\
\hline B5/T9/A & $\begin{array}{l}\text { Spanning distance between columns } 5 \mathrm{~m} \text {, } \\
\text { building height } 9 \mathrm{~m} \text {, number of inpatient } \\
\text { rooms } 10 \text { rooms, building form } 2 \text {. }\end{array}$ \\
\hline B6/T9/A & $\begin{array}{l}\text { Spanning distance between columns } 6 \mathrm{~m} \text {, } \\
\text { building height } 9 \mathrm{~m} \text {, number of inpatient } \\
\text { rooms } 10 \text { rooms, building form } 2 \text {. }\end{array}$ \\
\hline B4/25/B & $\begin{array}{l}\text { Spanning distance between columns } 4 \mathrm{~m} \text {, } \\
\text { building height } 25 \mathrm{~m} \text {, number of inpatient } \\
\text { rooms } 10 \text { rooms, building form } 4 \text {. }\end{array}$ \\
\hline B5/25/B & $\begin{array}{l}\text { Spanning distance between columns } 5 \mathrm{~m} \text {, } \\
\text { building height } 25 \mathrm{~m} \text {, number of inpatient } \\
\text { rooms } 10 \text { rooms, building form } 4 \text {. }\end{array}$ \\
\hline B6/25/B & $\begin{array}{l}\text { Spanning distance between columns } 6 \mathrm{~m} \text {, } \\
\text { building height } 25 \mathrm{~m} \text {, number of inpatient } \\
\text { rooms } 10 \text { rooms, building form } 4 \text {. }\end{array}$ \\
\hline
\end{tabular}

Table 6. Comparison of Estimated Volume and Real Volume on Validation Samples with P2V5 Modeling for Wallpapers Work

\begin{tabular}{llll}
\hline $\begin{array}{l}\text { Project } \\
\#\end{array}$ & $\begin{array}{l}\text { Actual wall } \\
\text { pair work } \\
\text { volume value } \\
\left(\mathrm{m}^{2}\right)\end{array}$ & $\begin{array}{l}\text { Wall pairing } \\
\text { volume value } \\
\text { by ANN }\left(\mathrm{m}^{2}\right)\end{array}$ & $\begin{array}{l}\text { Percentage } \\
\text { error/ } \\
\text { MMRE (\%) }\end{array}$ \\
\hline 11 & $3,772.58$ & $3,908.32$ & 3.59799 \\
12 & $3,772.58$ & $3,877.51$ & 2.78140 \\
13 & $1,691.44$ & $1,699.04$ & 0.44925 \\
14 & $1,691.44$ & $1,692.94$ & 0.08865 \\
15 & $4,903.87$ & $4,908.11$ & 0.08645 \\
\hline
\end{tabular}

Table 7. Comparison of Estimated Volume and Real Volume on Sample Validation with P2V5 Modeling for Plafond Work

\begin{tabular}{llll}
\hline $\begin{array}{l}\text { Project } \\
\#\end{array}$ & $\begin{array}{l}\text { Actual plafond } \\
\text { volume value } \\
\left(\mathrm{m}^{2}\right)\end{array}$ & $\begin{array}{l}\text { Volume of } \\
\text { plafond work } \\
\text { by ANN }\left(\mathrm{m}^{2}\right)\end{array}$ & $\begin{array}{l}\text { Percentage } \\
\text { error/ } \\
\text { MMRE }(\%)\end{array}$ \\
\hline 11 & $2,481.51$ & $2,486.35$ & 0.19488 \\
12 & $2,481.51$ & $2,467.78$ & 0.55320 \\
13 & 958.19 & 971.25 & 1.36280 \\
14 & 978.38 & 968.59 & 1.00027 \\
15 & $2,181.07$ & $2,178.37$ & 0.12396 \\
\hline
\end{tabular}

Table 8. Comparison of Estimated Volume and Real Volume on Sample Validation with P2V5 Modeling for Ceramic Floor Pair Work

\begin{tabular}{llll}
\hline $\begin{array}{l}\text { Project } \\
\#\end{array}$ & $\begin{array}{l}\text { Actual floor } \\
\text { volume value } \\
\left(\mathrm{m}^{2}\right)\end{array}$ & $\begin{array}{l}\text { The volume of } \\
\text { floor work by } \\
\text { ANN }\left(\mathrm{m}^{2}\right)\end{array}$ & $\begin{array}{l}\text { Percentage } \\
\text { error/ } \\
\text { MMRE }(\%)\end{array}$ \\
\hline 11 & $1,869.29$ & $1,875.66$ & 0.34069 \\
12 & $1,869.29$ & $1,859.14$ & 0.54321 \\
13 & 897.69 & 904.13 & 0.71760 \\
14 & 897.69 & 899.21 & 0.16954 \\
15 & $2,115.35$ & $2,114.77$ & 0.02715 \\
\hline
\end{tabular}

The highest error value based on Figure 8 for estimated volume requirement is $3.598 \%$. This value is much better than the value in other ANN modeling. The empirical formula used to estimate the needs of the work volume of the best wall, ceiling and floor tiles used is the formula of P2V5 modeling:

$$
\begin{aligned}
Y_{1}= & 4983.01+\left(\left(0.1 .02405 Z_{1}+11.38280 Z_{2}-0.03716 Z_{3}-\right.\right. \\
& 5.52954 Z_{4}+13.06117 Z_{5}+1.32395 Z_{6}-3.46593 Z_{7}+ \\
& \left.\left.1.38543 Z_{8}-0.91247 Z_{9}-5.36253\right) 1422.35\right) \\
Y_{2}= & 2867.42+\left(\left(1.61740 Z_{1}+0.59030 Z_{2}-1.63402 Z_{3}-\right.\right. \\
& 3.80567 Z_{4}+9.28277 Z_{5}+0.70382 Z_{6}-10.55386 Z_{7}+ \\
& \left.\left.1.37523 Z_{8}+1.03916 Z_{9}-4.91362\right) 821.23\right) \\
Y_{3}= & 2685.45+\left(\left(-0.92611 Z_{1}+0.59030 Z_{2}-1.60449 Z_{3}-\right.\right. \\
& 3.73540 Z_{4}+13.90184 Z_{5}-1.38817 Z_{6}-4.14168 Z_{7}- \\
& \left.\left.1.36588 Z_{8}+1.41732 Z_{9}-2.84898\right) 786.43\right)
\end{aligned}
$$

with:

$$
\begin{array}{ll}
\mathrm{Z}_{1}=\quad & 1 /\left(1+\exp ^{\wedge}\left(-\left(0.00024 X_{1}+4.11834 X_{2}+\right.\right.\right. \\
& 1.63632 X_{3}+1.21577 X_{4}+3.00195 X_{5}- \\
& 9.22430)) \\
\mathrm{Z}_{2}=\quad & 1 /\left(1+\exp ^{\wedge}\left(-\left(0.09624 X_{1}+0.00888 X_{2}-\right.\right.\right. \\
& 5.61824 X_{3}+5.16019 X_{4}-3.08231 X_{5}+ \\
& 0.11689)) \\
\mathrm{Z}_{3}=\quad & 1 /\left(1+\exp ^{\wedge}\left(-\left(-0.02831 X_{1}+1.74647 X_{2}+\right.\right.\right. \\
& 8.05015 X_{3}-0.18022 X_{4}-2.67898 X_{5}+ \\
& 7.16830))
\end{array}
$$




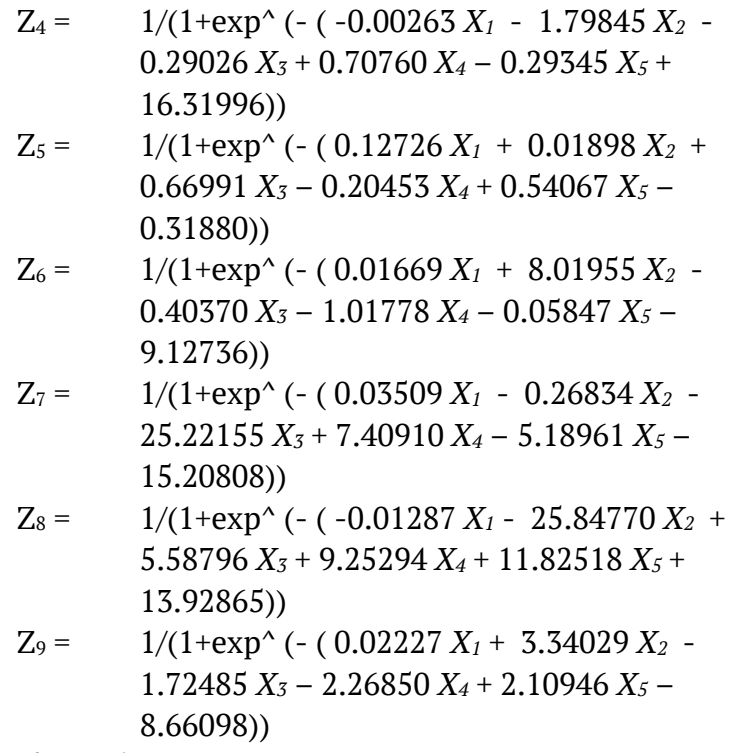

Information:
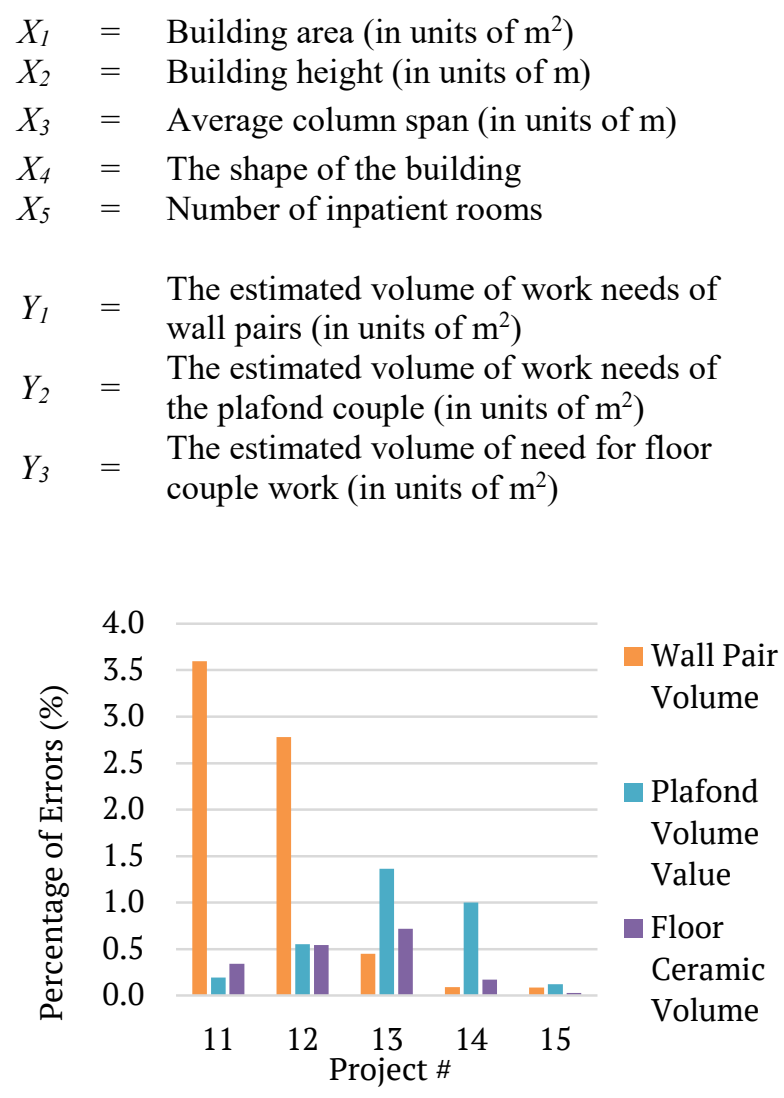

Figure 8. Percentage Error Requirement Volume of Architectural Work Components on Modeling P2V5

\section{CONCLUSIONS}

Based on the results and discussion, it was found that the accuracy value for P2V5 modeling had a percentage rate of $98.60 \%$. The best modeling to find the estimated volume of work needs of wall pairs, ceilings, and ceramic floor at the conceptual stage can be searched using P2V5 modeling. In such a method, 5 initial variables were used to find the value of the needs of components of architectural work (Table 9). The parameters are $X_{1}$ as building area (in units of $\mathrm{m}^{2}$ ), $X_{2}$ as building height (in units of $\mathrm{m}$ ), $X_{3}$ as average column span (in units of $\mathrm{m}$ ), $X_{4}$ as the shape of the building and $X_{5}$ as number of inpatient rooms.

Table 9. Model Architect Network of P2V5

\begin{tabular}{ll}
\hline Network Architect & Value \\
\hline Number of Input Layer used (X) & 5 \\
The number of Hidden Layers used & 1 \\
The number of Neurons in the Hidden & 9 \\
Layer used (Z) & \\
Number of Output Layer used (Y) & 3 \\
Iteration limit (epoch) & 100000 \\
Maximum target error (Emax) & 0 \\
Train netparam show & 250 \\
\hline
\end{tabular}

The Artificial Neural Network method examined the problem solving from the examples so that the performance of artificial neural network models for the estimation of the volume work needs of wall, ceiling and floor pairs depended on the quality and quantity of the input samples in the training process. Thus, the more examples there are, then the resulting formula will be high accuracy value. Thus, to study modeling and prediction methods, and to model the ANN for the volume requirements of architectural work components on an accurate conceptual framework, needed for reliability, high quality, and a large variety of input data are required. The main disadvantage of this method of estimating the volume requirement of this component of architectural work is that this formula can only be used to predict the need of working volume of wall pairs, ceilings and floors for the type of RS Pratama building with a maximum building area of $5000 \mathrm{~m}^{2}$ and a maximum height of 30 $\mathrm{m}$. This is because the input and training formulas on ANN modeling P2V5 have only limited input data. For development when there is real data that exceeds these limits, the ANN formula from modeling can be further developed to broaden its predictions coverage. Based on the empirical formula produced this proves that artificial neural networks can reduce the uncertainty related to the estimated volume of work needs of wall pairs, ceilings, and floors required in the construction of Pratama Hospital.

\section{REFERENCES}

Hegazy, T. and A. Ayed., 1998. A Neural Network Model for Parametric Cost Estimation of Highway Projects. Journal of Construction Engineering and Management, ASCE, Vol. 24 No.3, 210-218. 
Kesturi, L., 2012. Estimasi Biaya Tahap Konseptual pada Konstruksi Gedung Perkantoran dengan Metode Artificial Neural Network. Jakarta: Tesis. Universitas Indonesia.

Kusumadewi, S., 2004. Membangun Jaringan Saraf Tiruan Menggunakan MATLAB \& Excel Link. Yogyakarta: Penerbit Graha Ilmu.

Mohamed A, Celik T. Knowledge Based-System For Alternative Design, Cost Estimating And Scheduling. Knowl Based Syst 2002; 15:177-88.
Rumelhart D., Hinton G. and Williams R., 1986. Learning Internal Representations by Error Propagation. U.S.A: Cambridge: MIT Press.

S.Zeynep. Dogan, 2004. A Neural Network Approach for Early Cost Estimation of Structural System of Buildings www.elsevier.com/locate/ijproman

Saner C., 1993. A Proposal for Cost-Estimation for Structural Systems of 4-8 Storey Residential Buildings. MSc Thesis, Istanbul Technical University 
[This page is intentionally left blank] 